\title{
Motivating College Students' Learning English for Specific Purposes Courses through Corpus Building
}

\author{
Lin-Fang $\mathrm{Wu}^{1}$ \\ ${ }^{1}$ Language Education Center, Fooyin University, Taiwan \\ Correspondence: Lin-Fang Wu, Lecturer, Language Education Center, Fooyin University, Kaohsiung, Taiwan. \\ Tel: 886-7-781-1151 ext. 5629. E-mail: en018@fy.edu.tw
}

Received: January 27, 2014 Accepted: March 21, 2014 Online Published: May 15, 2014

doi:10.5539/elt.v7n6p120 URL: http://dx.doi.org/10.5539/elt.v7n6p120

\begin{abstract}
This study was conducted to determine how to motivate technical college students to learn English for specific purposes (ESP) courses through corpus building and enhance their language proficiency during the coursework for their majors. This study explores corpus building skills, how to simplify ESP courses by corpus building for English as second language learners, and ESP course evaluations. Although ESP programs have been implemented in technical colleges in Taiwan for several years, many students and educational practitioners feel frustrated regarding the academic achievement of learners' ESP courses. Corpus building is crucial for implementing an ESP program and its subsequent success. Designing appropriate teaching materials enables learners to overcome their fears when taking ESP courses. Numerous linguistic professionals have mentioned that ESP courses are aimed at advanced learners. However, the vocabulary size of most technical college students is below 2000 words in Taiwan. Teaching an ESP course at a technical university is challenging work for ESP teachers. Constructing an ESP corpus and selecting appropriate ESP vocabulary to meet learner needs is essential. Building a localized corpus and designing appropriate ESP materials based on student language proficiency is the future trend for ESP courses. In this study, we discuss basic rules for developing linguistics corpora, how to build localized corpora, and the most commonly used tutorials for corpus building.
\end{abstract}

Keywords: corpus, ESP courses, ESP vocabulary, technical college students

\section{Introduction}

Globalization has caused ESP courses to grow more rapidly in the past few decades. ESP courses gradually become the mainstream for second language learning worldwide. However, second language learners at technical colleges in Taiwan often feel frustrated about taking ESP courses because of limited vocabulary size. In addition, corpus building skills for second language teachers is often under evaluated. Abstract vocabulary and a difficult context can foster low levels of motivation among students taking the ESP courses. Corpora-based teaching materials simplify and systemize ESP courses. Motivating college students to learn ESP courses through corpus building can bridge the gap between ESP and English as a second language. In this study, the researcher introduces the skills related to designing ESP courses that involve corpus building. These skills comprise both simplifying and evaluating the courses, and teaching strategies. Effective and appropriate teaching strategies can motivate struggling second language learners to enroll in ESP courses. Vocabulary learning strategies are addressed because ESP vocabulary knowledge is closely related to reading comprehension in ESP courses. Designing a corpus-based ESP course enables technical college students to have an effective learning. Sinclair (2003) indicated that the purpose of building a corpus is for studying language. A corpus consists of a databank of natural texts, compiled from writing or a transcription of recorded speech (Krieger, 2005). Burnard (1995) mentioned that corpus linguistics is an empirical science, in which the investigator seeks to identify patterns of linguistic behavior by inspecting and analyzing naturally occurring samples of language. A typical corpus analysis collects numerous examples of linguistics usage, each taken from the text in which it originally occurred, similar to a laboratory specimen. The advent of the electronic age has increased the possibility of electronic corpora in the last few decades. Linguists have been overburdened regarding the relation between a corpus and a language. However, no corpus represents the original characteristics of language. Linguists discover communicative patterns by analyzing authentic documents and speech events. Limited vocabulary is the primary obstacle for technical college students in comprehending English textbooks. Huang (2007) has indicated 
that the vocabulary of most non-English-major technical college students is below 2000 words in Taiwan. Nation (2001) suggested that college students must recognize $95 \%$ of a reading text before they can comprehend it. Several researchers (Huang, 2007; Yang, 2002) have also mentioned that word mastery learned at a vocational high school and junior college in Taiwan wasn't required for the reading content of college English textbooks. Consequently, corpus building skills for various academic disciplines are necessary and crucial for both language teachers and content teachers who should learn how to use corpus building software and analyze the results. ESP courses based on word lists and concordances become a trend for ESP instructors when teaching ESP courses. ESP instructors should design curriculum based on acceptable data, such as English textbooks, documents, and information in a specific disciplines to enhance learners' word power and improve their reading proficiency. Designing content-based courses by building a textbook-based and localized corpus is crucial for implementing successful ESP programs. In addition, it is helpful to prepare proper exercises and classrooms activities for listening, speaking, reading, and writing. Developing ESP course materials, selecting course content, and networking with other community colleges are essential elements for the academic English as a second language (Perkins, 1993).

\section{Principles for Corpus Building}

Developing linguistic corpora is the core of ESP programs. Sinclair (2003) indicated that corpus is remarkable, not because it is a collection of texts, but because it is effectively designed and carefully constructed. However, many language teachers are confused regarding the procedures of corpus buildings. The followings guidelines have been suggested for corpus buildings (Sinclair, 2003; Krishnamurthy, 2005).

\subsection{Corpus Builders}

Corpus should be designed and built by an expert in the communicative patterns of the communities who use the language that the corpus will mirror. The corpus analyst should accept whatever is selected by corpus experts, regardless of the contents of the documents and speech events. However, documents should be selected based on specific group of people are writing and reading, and the according to the types of conversations they are having (Sinclair, 2003).

\subsection{Criteria}

Selection criteria that are derived from examining the communicative function of a text are called external criteria, and those that reflect the language details of the text are called internal criteria. Corpora should be designed and constructed based exclusively on external criteria (Clear, 1992).

\subsection{Corpus Composition}

A corpus attempts to represent a language or part of a language rather than merely a collection of texts (Biber, 2001). Corpus builders must first consider what types of data to include in the corpus and in what proportions (Krishnamurthy, 2005). Moreover, most current corpora are poorly balanced because they are insufficient in spoken language. Another factor affecting balance is the degree of text specialization which can give the impression of imbalance (Sinclair, 2003).

\subsection{Corpus Size}

Maximum corpus size is stipulated because the collection of texts is dynamic and open-ended. However, the size of the corpus is known from the outset, and the target to be reached, marks the end of the data collection phase (Krishnamurthy, 2005).

\subsection{Data Collection Staff and Document Format}

In contrast to the corpus builders, the data collection staff are typically unqualified people on low-paid, short-term contracts with scant interest in the later corpus stage. Therefore, corpus builders must ensure that they all record the same information regarding the documents collected and use the same format (Krishnamurthy, 2005).

\subsection{Representatives of Corpora Data}

1) Decide the structural criteria to build the corpus and apply it to create a framework for the principal and corpus components

2) Draw up a comprehensive inventory of text types by using external criteria only

3) Put the text types in priority order, accounting for all factors that increase or decrease the importance of a text (Sinclair, 2003) 


\subsection{Corpus Building Software}

Corpus building software is a crucial instrument for corpus building. Flexible and speedy software is essential for researchers designing a special domain corpus. The most commonly used corpus tools are concordancers. Concordancing is the process of using software to search all the occurrences of a target word or phrase in a corpus (O'Keeffe \& Farr, 2003). The following are examples of corpora suggested by Chen (2004) and Krieger (2005).

\subsection{Corpora Examples}

British National Corpus

The British National Corpus (BNC) is one of the most famous corpora consisting of 100 million collections of written and spoken language samples.

http://www.natcorp.ox.ac.uk.

The International Corpus of English (IEC)

The International Corpus of English consists of 100 million spoken and written English samples. The ICE provides both authentic written and spoken English samples of various English varieties.

http://www.edict.com.hk/cordance

Corpus Concordance English

http://www.lextutor.ca/concordancers/concord_e.html

\section{Implementing ESP Courses for Technical College Students}

\subsection{Basic 2000-Word Vocabulary before Commencing ESP Courses}

Several language professionals (Kirschner, 1992; Huang, 2007) have indicated that ESP courses should be taught after learners have reached an intermediate level of English language proficiency. Coday and Huckin (1997) suggested that foreign language learners should recite the 2000-3000 most commonly used words. However, Joe and $\mathrm{Wu}$ (2001) mentioned that the vocabulary of most technology college students is below 2000 words in Taiwan. Training to achieve basic 2000 -word vocabulary is required before students take ESP courses. After passing a basic 2000-word vocabulary test, selecting an appropriate ESP vocabulary size becomes another challenging task.

\subsection{Applying Textbook-Based and Localized Corpus to ESP Teaching}

Huang (2007) indicated that textbook-based corpus can be applied to ESP courses to assist technical college students in overcoming learning difficulties and enhancing their learning motivation. With the help of a subject teacher, the language teacher should build a textbook-based corpus before designing ESP courses and a localized corpus as part of ESP courses. The corpora should be collected from localized organizations, such as banks, hospitals and industrial companies. Incorporating English textbooks-based corpora and localized corpora is beneficial for technical college students.

\subsection{Selecting Appropriate ESP Vocabulary for Technical College Students}

After students pass the for basic 2000-word vocabulary test, ESP teachers should select an appropriate sized ESP vocabulary for technical college students, including a textbook-based corpus, the commonly used spoken corpus and the localized authentic documents.

\section{ESP Courses Teaching Strategies}

\subsection{Building a Comprehensive Text Corpus}

Recent studies have identified lexical competence as the most substantial predictor of general language ability (Carter \& McCarthy, 1988). Nababan (1993) indicated ESP vocabulary as the central core of ESP programs, and that the vocabulary component is the most prominent feature of a register. The exact meanings of words rely on the particular register in which they are used. However, inadequate vocabulary knowledge is the primary hindrance for technical college students reading English textbooks. Consequently, corpus building is crucial when educators are implementing ESP courses. With the advent of computer technology, computer software packages have contributed substantially to corpus building.

Sinclair (1998) indicated that a corpus-based analysis can investigate nearly any language patterns, such as lexical, structural, or lexical-grammatical. Given the appropriate analytical tools, an investigator can discover language-use patterns, and the extent to which they are used (Krieger, 2005). Barlow (2002) suggested that 
language teachers apply corpus into syllabus design, material development and classroom activities. Register information and word frequency are also useful for planning ESP courses. Language teachers should develop teaching materials and academic assessment according to student needs and language proficiency by using corpus data.

\subsection{Raising Phonological Consciousness in ESP Classrooms}

The shifting language teaching methods rarely focused on the importance of pronunciation (Steracci, 1997). Most ESP instructors emphasize genre analysis by using computer software. ESP vocabulary is the primary aspect of academic assessment when implementing ESP programs. Beisbier (1995) indicated that pronunciation is crucial in achieving communicative objectives in the communicative process. $\mathrm{Wu}(2005)$ asserted phonetic irregularity to be a primary hindrance for learners in ESP classrooms because most terminology involves multi-syllabic words that are longer and more complex than commonly used words. The different pronunciation between ESP instructors and clinical instructors at hospitals frequently frustrates nursing students.

In support of Wong's statement, Steracci (1997) indicated that ESP instructors should focus on pronunciation in ESP classrooms. Phonological consciousness can be an effective approach to help learners achieve accurate pronunciation and communicative objectives. Steracci asserted that native-like pronunciation is not the goal. However, accurate pronunciation is required for learners to achieve communicative objectives. ESP instructors should build phonological skills in the classroom and collect voice samples to assist learners in identifying regional accents within American and British English. Learners should become familiar with diverse pronunciations to achieve communicative goals in various situations. Pennington (1997) suggested that developing listening comprehension facilitate learners in bridging communication gap.

\subsection{Simplifying ESP Texts for Technical College Students}

ESP texts are often extremely difficult for undergraduate university students in an English as a foreign language (EFL) situation. Attempting to read ESP texts is difficult for a native English speaker whose major is not in that field (Noguchi, 1997). Several researchers (Joe \& Wu, 2001) have mentioned that the vocabulary of most technical college students in Taiwan is below 2000 words. However, Bhati (1993) indicated that simplifying the material is not the answer. Simplifying ESP courses involves expansion resulting from paraphrasing and detransforming, which might obscure and destroy the generic integrity of the text. He suggested that simplifying ESP courses by using various devices without making drastic changes to the content can effectively guide readers through a text.

Noguchi (1997) indicated that genre analysis, reading portfolios, and purpose, audience, information, and language (PAIL) are the most effective methods to simplify ESP courses for EFL technical college students. The genre analysis approach is a powerful tool to assist students in their major field. Noguchi (1997) suggested that reading portfolios should be collected based on consultations with professionals in that field. A reading portfolio of ESP texts enables learners to continue studying and working. PAIL is a type of ESP teaching strategy that assists learners in comprehending various texts with diverse purposes. Swales (1990) mentioned that PAIL helps students to recognize genre characteristics and subsequently retrieve information from a text. The PAIL definitions are as follows (Noguchi, 1997):
$\mathrm{P}=$ purpose
Why was this text written?
$\mathrm{A}=$ audience
Who was it written for?
$I=$ information
What kind of information does it contain?
$\mathrm{L}=$ language
What are its language features?

\subsection{Overcoming ESP Vocabulary Learning Difficulties by Using Vocabulary Learning Strategies}

People typically attempt to remember a word according to lexical units which enable learners to memorize vocabulary effectively. Therefore, exercises to enhance storage and recall should be centered on these forms. Word formation is a crucial strategy for learners to memorize related words. The knowledge of basic affixes, roots, suffixes, and word formation enables learners to decode them. Decomposing an unknown word into its structural components infer its meaning is called structural analysis. ESP vocabulary learners should be taught the basic strategies of decomposing a word into parts to guess its meaning. Several studies have reported using various affixes to teach students to structurally analyze ESP vocabulary. The instruction resulted in large gains in student abilities to infer word meanings. Familiarizing students with morphological units and lexical collocations will enable them to recognize the meaning of numerous words. In addition, teaching the word formation of ESP vocabulary can assist learners to memorize and recognize vocabulary effectively (Nation, 1990). 


\section{ESP Course Design and Evaluation}

\subsection{ESP Course Design Based on Learner Needs Analysis}

Vocabulary teaching materials are critical when designing ESP teaching materials. Jones and Durrant (2010) indicated that lists of crucial vocabulary have long been used by ESP teachers to design courses and prepare materials, and corpus data is the foundation for developing these vocabulary lists. Vocabulary selection is the most substantial basis for establishing a structural syllabus. The basic procedure for ESP course design is to determine the syllabus content based on linguistic items by referring to primary criteria such as frequency, range, and coverage (Widdowson, 1968). Nababan (1993) mentioned the vocabulary component as the core of numerous ESP programs. Vocabulary is the most prominent feature of a register, and words have exact meanings depending on the particular register in which they are used. Therefore, integrating ESP courses with vocabulary storage strategies should be the priority when designing ESP courses.

Corpus building based on learner needs is essential for designing ESP courses. Nababan (1993) indicated that the specific disciplines and the types of learners are crucial elements for designing ESP teaching programs. Needs analysis is fundamental for designing ESP courses related to specific disciplines and ESP teaching materials should be based on a syllabus that covers the needs of learners in their current studies or future professions. ESP teaching content can be determined through needs analysis. Munby (1978) suggested that the syllabus specification for ESP materials derives directly from previous identifying the communicative needs of particular learners. Learner needs should be the first criteria for ESP course design. After the content has been recorded, analyzed, and organized, teachers and learners will experience efficient learning and teaching.

\subsection{ESP Courses Evaluation}

ESP course evaluation should be conducted during and at the end of the semester (Dudley-Evans, 1997). A primary learning objectives for ESP course learners is to take an academic course in English for further education in English speaking countries, such as Britain, USA, and New Zealand. Mastering English for use in a future career is another crucial goal for learners. At the onset of an ESP course, the ESP teacher should establish learning objectives based on the learner needs. During the course, teaching materials and teaching techniques can be adjusted according to the learner responses. Gauging learners' ability to what extent they have learned and how they can apply it in the workplace or in academic classes are critical.

\section{Conclusion and Recommendation}

Corpora language instruction and research are a recent trend, particularly for ESP courses. Several researchers and language teachers have applied copra into their language research and teaching, and language teaching has emphasized using corpora and concordancing (Watson, 2001). Corpus analysts, computer software, data collectors are the primary components for corpus building. However, corpora and concordancing use is restricted to large institutions because the procedure is costly. The cost of converting paper text into electronic text is much greater than the cost of copying, downloading and gathering digitized data (Sinclair, 2003). In addition, most teachers and students seldom participated in the corpus building process. Building and using a personal corpus based on learners' needs substantially benefits classroom learners. Teachers and learners who build their own corpora and concordance can effectively manage the learning difficulties of an ESP vocabulary. Teachers can build their own corpora to help learners select target words from academic articles. Watson (2001) indicated student selected-concordances assist them in inducing the concordances rules of use and in self-correcting learners' written work. Yoon (2005) used a corpus to teach academic writing to students and observed that corpus-based pedagogy raises learner awareness of grammar in language learning. Encouraging learners and students to build their own corpora and concordances can be an effective English-teaching technique.

Complex factors, such as motivation, language proficiency, family background, gender differences, and learning strategies, affect ESP course acquisitions. Motivation is the primary factor in learning a second language in both ESP and general English courses. Technical college students enrolled in ESP courses often exhibit low motivation levels because of frustration with their insufficient language abilities. Corpus building enables language teachers to organize and simplify ESP teaching materials; thus, second language learners feel comfortable and their motivation is enhanced. Learners who posses integrative motivation and self-confidence can address their learning problems. Corpora data provide learners with multiple examples of lexical and syntactic patterns. Thus, using data-driven teaching methods can enable language learners develop integrative motivations. Systemized corpora and effective language teaching approaches can reduce the anxieties of lowperforming learners and motivate them to express enthusiasm toward learning ESP courses. Corpora language instruction plays a crucial role in the ESP courses of second language learners. 
Morphology is another crucial element that facilitates effective learning among second language learners taking ESP courses. Morphological productivity through corpora data examples can markedly assist learners. Laufer (1997) reported several difficulties involved in learning ESP vocabulary, such as pronunciation ability, orthography, length, morphology, synformy, abstractness, register restrictions and multiple meanings. Analyzing word formation can deepen learner understanding regarding both the ESP vocabulary and texts. Corpora data enhance the morphological productivity of learners. The integration of ESP and morphology-related courses enables learners to readily memorize the orthography of ESP vocabulary. In addition, word frequency can enable course designers to select vocabulary that meet learner needs, whereas concordance enables learners to undergo integrative learning, thereby facilitating their understanding of abstractness in ESP vocabulary and texts. ESP instructors can design morphology-related exercises, enabling learners to practice using free online concordance samples; thus, involving corpora when teaching ESP courses can foster enhanced levels of motivation, understanding, and proficiency among learners.

Data-driven teaching and learning approaches are beneficial in both ESP courses and general English courses. ESP courses designed using corpus building can be developed in the fields of listening, speaking, and writing. ESP courses instructors should also provide general information for learners, regarding how to use genre-based language corpora, build their corpora and manage corpora data. Other critical steps include giving an introduction about how to operate corpora data analysis tool, preparing learners to query the data, getting to know a concordancer, training learners to read and interpret concordance lines and providing technical support for learners (Sripicharn, 2012). Providing training and knowledge related to preparing corpus-based materials for language teachers is critical when implementing ESP programs. Encouraging learners to build their own corpora can be an effective English-teaching technique. In short, the applications of corpus linguistics in teaching ESP courses become more and more indispensable in the electronic age.

The limitation of this study was the lack of data regarding corpora-based classroom activities. Subsequent studies should collect empirical data by designing ESP courses and building corpora by using appropriate teaching materials. Analyzing such teaching materials should elucidate various aspects of foreign language teaching, including ESP and general English courses.

\section{Acknowledgments}

The author gratefully acknowledges the two teachers at Fooyin University, Taiwan who inspired this research and provided relevant knowledge regarding ESP course design, corpus building, and the applications of ESP courses.

\section{References}

Barlow, M. (2002). Corpora, concordancing, and language teaching. Paper presented at Proceedings of the 202 KAMALL International Conference, Daejon, Korea.

Beisbier, B. (1995). Sounds great: Intermediate pronunciation and speaking for learners of English. Boston, MA: Heinle and Heine.

Bhati, T. (1993). Variety in Written English: Texts in society. London and New York: Routlege.

Biber, D., \& Conrad, S. (2001). Corpus based research in TESOL. TESOL Quarterly, 35(2), 331-335. http://dx.doi.org/10.2307/3587653

Burnard, L. (1995). Users' reference guide to the British National Corpus. Oxford: Oxford University Computing Services.

Carter, R., \& McCarthy, M. (1988). Vocabulary and Language Teaching. New York: Longman.

Chen, Y. H. (2004). The Use of Corpora in the Vocabulary Classroom. The Internet TESL Journal, 10(9). Retrieved December 18, 2013, from http://iteslj.org/Techniques/Chen-Corpora.html

Clear, J. (1992). Corpus Sampling: New Directions in English Language Corpora. Berlin: Mouton de Gruyter.

Coday, J., \& Huckin, T. (1997). Second language vocabulary acquisition: A rational for pedagogy. New York: Cambridge University Press.

Dudley-Evans, T. (1997). An overview of ESP in the 1990s. In T. Orr (Ed.), Proceedings 1997: The Japan Conference on English for Specific Purposes (pp. 5-12). Japan: University of Aizuwakamatsu.

Huang, C. C. (2007). Applying a textbook-based corpus to promote business students' reading comprehension. In Y. Chen (Ed.), The Proceedings of International Symposium on ESP \& Its Application in Nursing \& Medical English Education (pp. 342-362). Taiwan: Fooyin University. 
Joe, S. G., \& Wu, S. R. (2001). Comprehension strategies and monitoring strategies used by college students in reading scientific text. Paper presented at The Proceedings of the Second Conference on Interactive English Teaching at Chin Min College, Miaoli, Taiwan.

Jones, M., \& Durrant, P. (2010). What can a corpus tell about vocabulary teaching materials. In A. O'Keeffe, \& M. McCarthy (Eds.), The Routledge handbook of corpus linguistics (pp. 387-400). New York: Routledge.

Kirschner, M. (1992). ESP A reader responds......TESOL Matters, October/November.

Krieger, D. (2005). Corpus Linguistics: What It Is and How It Can Be Applied to Teaching. The Internet TESL Journal, 9(3). Retrieved November 15, 2013, from http://iteslj.org/Articles/Krieger-Corpus.html

Krishnamurthy, R. (2005). Corpus Construction: Principles, Practices, and Problems. Report presented at National Tsing Hua University, Hsinchu, Taiwan.

Laufer, B. (1997). What's in a word that makes it hard or easy: Some intralexical factors that affect the learning of words. In M. McCarthy, \& N. Schmitt (Eds.), Vocabulary: Description, Acquisition and Pedagogy (pp. 140-155). Cambridge: Cambridge University Press.

Munby, J. (1978). Communicative Syllabus Design. Cambridge: Cambridge University Press.

Nababan, P. W. J. (1993). E.S.P. Materials Preparation in a Foreign Language Situation. ERIC Digest.

Nation, I. S. P. (1990). Teaching and learning vocabulary. New York: Newbury House.

Nation, I. S. P. (2001). Learning Vocabulary in another language. Cambridge: Cambridge University press. http://dx.doi.org/10.1017/CBO9781139524759

Noguchi, J. (1997). Easifying ESP Courses for EFL Science Majors. In T. Orr (Ed.), Proceedings 1997: The Japan Conference on English for Specific Purposes (pp. 13-19). Japan: University of Aizuwakamatsu.

O' Keeffe, A., \& Farr, F. (2003). Using language corpora in initial teacher education: Pedagogic issues and practical applications. TESOL Quarterly, 37(3), 389-418. http://dx.doi.org/10.2307/3588397

Pennington, M. (1997). Acquiring proficiency in English phonology: Problems and solutions for Japanese learners. Nagoya Gakuin Daigaku, Gaikokugo Kyoikukiyo, 16.

Perkins, C. D. (1993). Vocational and Applied Technology Education Program. ERIC Document Service. ED374 3259.

Sinclair, J. (2003). Corpora for lexicography: A practical guide to lexicography. Sterkenberg. Amsterdam: John Benjamins.

Sinclair, J. (1998). Corpus evidence in language description. In G. Knowles, T. Mcenery, S. Filgelstone, \& S. Wichman (Eds.), Teaching and language corpora (pp. 27-39). New York: Longman.

Sripicharn, P. (2012). How can we prepare learners for using language corpora? In A. O'Keeffe, \& M. McCarthy (Eds.), The Routledge Handbook of Corpus Linguistics (pp. 371-384). New York: Routledge.

Steracci, P. (1997). Phonological Consciousness Raising Tasks for the ESP Classroom. In T. Orr (Ed.), Proceedings 1997: The Japan Conference on English for Specific Purposes (pp. 101-111). Japan: University of Aizuwakamatsu.

Swales, J. M. (1990). Genre analysis: English in academic and research settings. Cambridge, UK: Cambridge University Press.

Watson, T. R. (2001). Building and using your won corpus and concordance. Thai TESOL Bulletin, 14(2). Retrieved November 20，2013， from http://arts.kmutt.ac.th/call/doc/Building\%20and\%20Using\%20 Your\%200wn\%20Corpus\%20and\%20Concordance.pdf

Widdowson, H. G. (1968). The teaching of English through science. In J. Dakin, B. Tiffen, \& H. G. Widdowson (Eds.), Language in Education (pp. 115-175). Oxford: Oxford University press.

Wu, L. F. (2005). ESP Vocabulary Learning and Teaching. Paper presented at Proceedings of 2005 International Symposium on ESP \& Its Application in Nursing \& Medical English Education, Fooyin University, Kaohsiung, Taiwan.

Yang, Y. F. (2002). Developing the vocabulary size and analysis test for identifying TVES. The Proceedings of the Nineteenth International Conference on English Teaching and Learning (pp. 489-499). Taipei: Crane.

Yoon, H. (2005). An investigation of students' experiences with corpus technology in second language academic writing (Unpublished the doctoral dissertation, The Ohio State University, Columbus, $\mathrm{OH}$ ). 


\section{Copyrights}

Copyright for this article is retained by the author(s), with first publication rights granted to the journal.

This is an open-access article distributed under the terms and conditions of the Creative Commons Attribution license (http://creativecommons.org/licenses/by/3.0/). 